\title{
The first Negishi cross-coupling reaction of two alkyl centers utilizing a Pd-N-heterocyclc carbene (NHC) catalyst.
}

Niloufar Hadei, Eric Assen B. Kantchev, Christopher J. O’Brien and Michael G. Organ*

Department of Chemistry, York University, 4700 Keele Street, Toronto, Ontario, M3J 1P3

Canada

organ@yorku.ca

\section{Supporting Information}

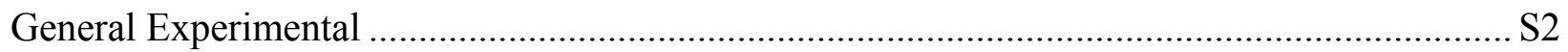

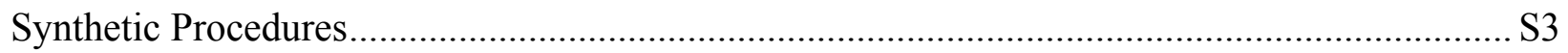

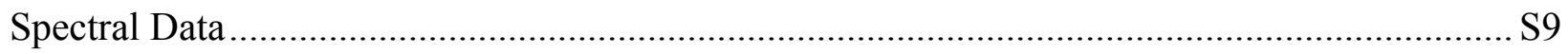

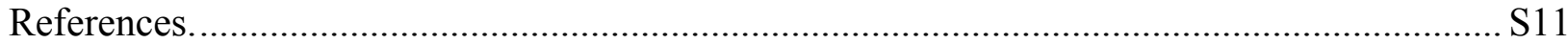




\section{General Experimental}

All reactions were carried out under an atmosphere of argon using Schlenk techniques. Glovebox manipulations were performed in an MBraun Unilab glove-box under an atmosphere of dry argon. All solvents and reaction vials (screw-cap threaded, caps attached, 17 x $60 \mathrm{~mm}$ ) were purchased from Fischer Scientific. $\mathrm{CDCl}_{3}$ was purchased from Cambridge Isotopes. Dry NMP and DME (stored over $4 \AA$ molecular sieves) were purchased from Fluka and handled under argon; THF was dried under argon over sodium-benzophenone; toluene and dichloromethane were dried under argon over $\mathrm{CaH}_{2}$; dry DMA was purchased from Aldrich and handled under argon; DMF was vacuum distilled over anhydrous $\mathrm{MgSO}_{4}$, stored over $4 \AA$ molecular sieves and handled under argon. All reagents were purchased from commercial sources and were used without further purification, unless indicated otherwise. All alkylzinc reagents were products of Rieke Metals, Inc. and purchased from Aldrich. 1,3-bis(2,6-diisoprylphenyl)imidazolium chloride (IPr· $\mathrm{HCl}, 4)$ and 1,3-bis(2,4,6-trimethylphenyl)imidazolium chloride (IMes $\cdot \mathrm{HCl}, 5)$ were prepared according to a published procedure. ${ }^{1}$ Thin layer chromatography (TLC) was performed on Whattman $60 \mathrm{~F}_{254}$ glass plates and were visualized using UV light $(254 \mathrm{~nm})$, potassium permanganate or phosphomolybdic acid stains. Column chromatography purifications were carried out using the flash technique on Silicycle silica gel 60 (230-400 mesh). NMR spectra were recorded on a Bruker $400 \mathrm{AV}$ spectrometer. The chemical shifts $(\delta)$ for ${ }^{1} \mathrm{H}$ are given in ppm referenced to the residual proton signal of the deuterated solvent. The chemical shifts $(\delta)$ for ${ }^{13} \mathrm{C}$ are referenced relative to the signal from the carbon of the deuterated solvent. Gas chromatography was performed on Varian Series GC/MS/MS 4000 System. 


\section{Synthetic Procedures}

Representative procedure for Table 1 (entry 1). A vial was charged with $\operatorname{Pd}_{2}\left(\mathrm{dba}_{3}(9.2 \mathrm{mg}\right.$, $0.010 \mathrm{mmol}), \mathrm{IPr} \cdot \mathrm{HCl}(17 \mathrm{mg}, 0.040 \mathrm{mmol})$ and a stirbar in the glove-box. The vial was sealed with a septum, removed from the glove box and dry THF $(0.3 \mathrm{~mL})$ and dry NMP $(0.8 \mathrm{~mL})$ added via syringe. After stirring for 5-10 min at $\mathrm{rt}$, $n$-butylzinc bromide $(1.3 \mathrm{~mL}$ of a $0.5 \mathrm{M}$ THF solution, $0.65 \mathrm{mmol}$ ) was added and the reaction mixture was stirred at $\mathrm{rt}$ for additional $15 \mathrm{~min}$. $N$-methylimidazole (50 $\mu \mathrm{L}, 49 \mathrm{mg}, 0.60 \mathrm{mmol}), 3$-Bromopropylbenzene $(99.5 \mathrm{mg}, 76 \mu \mathrm{L}, 0.5$ $\mathrm{mmol}$ ) and $50 \mu \mathrm{L}$ of $n$-undecane (GC internal standard) were added, the septum was replaced with a Teflon ${ }^{\circledR}$-line screw cap under an inert atmosphere ${ }^{2}$ and the vial was heated with stirring for $18 \mathrm{~h}$ at $75^{\circ} \mathrm{C}$. After cooling to $\mathrm{rt}$, the reaction mixture was diluted with hexane and passed through a short pad of silica gel and analyzed by GC/MS. The GC retention time and EI fragmentation pattern were identical to commercially available material (Aldrich).

Representative procedure for Table 2 (entry 7). A vial was charged with $\mathrm{Pd}(\mathrm{OAc})_{2}(4.4 \mathrm{mg}$, $0.02 \mathrm{mmol}), \mathrm{IPr} \cdot \mathrm{HCl}(17 \mathrm{mg}, 0.04 \mathrm{mmol})$ and a stirbar in the glove-box. The vial was sealed with a septum, removed from the glove box and dry THF $(0.3 \mathrm{~mL})$ and dry NMP $(0.8 \mathrm{~mL})$ added via syringe. After stirring for 5-10 min at rt, $n$-butylzinc bromide (1.3 mL of a $0.5 \mathrm{M}$ THF solution, $0.65 \mathrm{mmol}$ ) was added and the reaction mixture was stirred at $\mathrm{rt}$ for additional $15 \mathrm{~min}$. 3Bromopropylbenzene $(99.5 \mathrm{mg}, 76 \mu \mathrm{L}, 0.5 \mathrm{mmol})$ and $50 \mu \mathrm{L}$ of $n$-undecane (GC internal standard) were added, the septum was replaced with a Teflon ${ }^{\circledR}-$ line screw cap under an inert atmosphere $^{2}$ and the vial was heated with stirring for $18 \mathrm{~h}$ at $75{ }^{\circ} \mathrm{C}$. After cooling to $\mathrm{rt}$, the reaction mixture was diluted with hexane and passed through a short pad of silica gel and analyzed by GC/MS. The GC retention time and EI fragmentation pattern were identical to commercially available material (Aldrich). The reaction was performed with a catalyst prepared 
by weighing $\mathrm{Pd}(\mathrm{OAc})_{2}$ and $\mathrm{IPr} \cdot \mathrm{HCl}$ in air (following Schlenk techniques) without deterioration of yield.

General Procedure for Table 3: A vial equipped with a stirbar was charged with $\operatorname{Pd}_{2}\left(\mathrm{dba}_{3}\right)_{3}(9.2$ $\mathrm{mg}, 0.010 \mathrm{mmol})$ and $\mathrm{IPr} \cdot \mathrm{HCl}(17 \mathrm{mg}, 0.040 \mathrm{mmol})$ in a glove-box and the vial was capped with a septum. The vial was removed from the glove box and dry THF $(0.3 \mathrm{~mL})$ and dry NMP $(0.8$ $\mathrm{mL})$ were added via syringe. After stirring for 5-10 min at rt, $n$-butylzinc bromide $(0.12 \mathrm{~mL}$ of a $0.5 \mathrm{M}$ THF solution, $0.06 \mathrm{mmol}$ ) was added and the reaction mixture was stirred for $1 \mathrm{~h}$ at $\mathrm{rt}$, afterwhich alkylzinc reagent $(1.3 \mathrm{~mL}$ of a $0.5 \mathrm{M}$ THF solution, $0.65 \mathrm{mmol})$ and the alkyl bromide $(0.50 \mathrm{mmol})$ were added. The septum was replaced with a Teflon ${ }^{\circledR}$-line screw cap under an inert atmosphere ${ }^{2}$ and the solution stirred at $\mathrm{rt}$ for $24 \mathrm{~h}$. The reaction mixture was then transferred to a separatory funnel with diethyl ether $(10 \mathrm{~mL})$ and the organic layer successively washed with $1 \mathrm{M} \mathrm{Na}_{3}$ EDTA solution (prepared from EDTA and 3 eq. $\mathrm{NaOH}$ ), water, and brine. After drying over anhydrous $\mathrm{MgSO}_{4}$, the solution was filtered and concentrated and the residue purified by flash chromatography.

\section{Ethyl octanoate (6) CAS \# [106-32-1]}

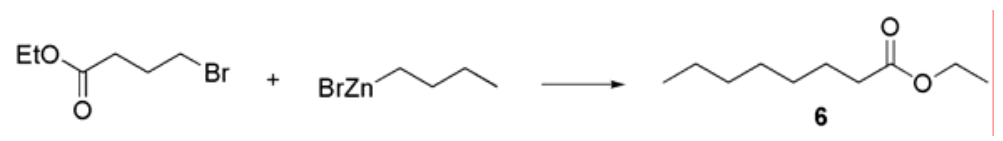

(Table 3, entry 1). Following the general procedure, $n$-butylzinc bromide $(1.3 \mathrm{~mL}$ of a $0.5 \mathrm{M}$ THF solution, $0.65 \mathrm{mmol}$ ) and ethyl 4-bromobutyrate $(97.5 \mathrm{mg}, 71 \mu \mathrm{L}, 0.5 \mathrm{mmol})$ provided 79 mg of 6, $92 \%$ yield.

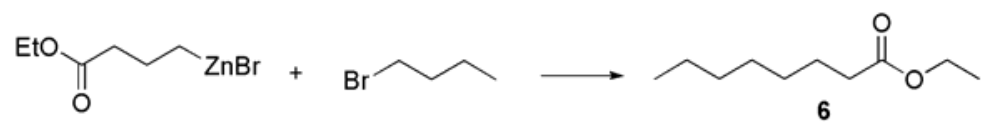


(Table 3, entry 4). Following the general procedure, 4-ethoxy-4-oxobutylzinc bromide $(1.3 \mathrm{~mL}$ of a $0.5 \mathrm{M}$ THF solution, $0.65 \mathrm{mmol})$ and 1-bromobutane $(68.5 \mathrm{mg}, 53 \mu \mathrm{L}, 0.5 \mathrm{mmol})$ provided $79 \mathrm{mg}$ of $6,92 \%$ yield.

Preparation without $n$-butylzinc bromide activation: A vial equipped with a stirbar was charged with $\mathrm{Pd}_{2}(\mathrm{dba})_{3}(9.2 \mathrm{mg}, 0.010 \mathrm{mmol})$ and $\mathrm{IPr} \cdot \mathrm{HCl}(17 \mathrm{mg}, 0.040 \mathrm{mmol})$ in a glove-box and the vial was capped with a septum. The vial was removed from the glove box and dry THF $(0.3 \mathrm{~mL})$ and dry NMP $(0.8 \mathrm{~mL})$ added via syringe. After stirring for 5-10 min at rt, 4-ethoxy-4oxobutylzinc bromide (1.3 $\mathrm{mL}$ of a $0.5 \mathrm{M}$ THF solution, $0.65 \mathrm{mmol})$ was added and the reaction mixture was stirred for $1 \mathrm{~h}$ at $\mathrm{rt}$, followed by addition of 1-bromobutane $(68.5 \mathrm{mg}, 53 \mu \mathrm{L}, 0.5$ mmol). From this point, the general procedure was followed. Provided $75 \mathrm{mg}$ of $6,87 \%$ yield. The ${ }^{1} \mathrm{H}$ NMR spectrum was identical to the spectrum included in the Aldrich database.

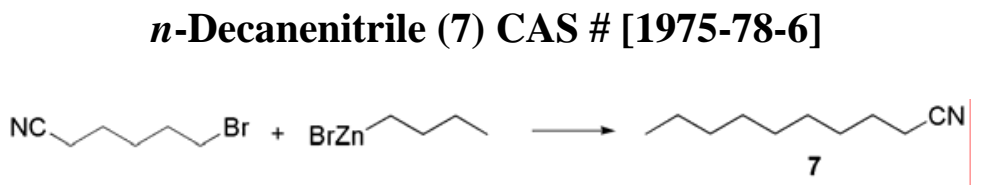

(Table 3, entry 2). Following the general procedure, $n$-butylzinc bromide $(1.3 \mathrm{~mL}$ of a $0.5 \mathrm{M}$ THF solution, $0.65 \mathrm{mmol})$ and 6-bromohexanonitrile $(88.0 \mathrm{mg}, 66 \mu \mathrm{L}, 0.5 \mathrm{mmol})$ provided 70 mg of 7, $92 \%$ yield. The ${ }^{1} \mathrm{H}$ NMR spectrum was identical to the spectrum included in the Aldrich database.

$N$-octylphthalimide (8) CAS \# [59333-62-9]

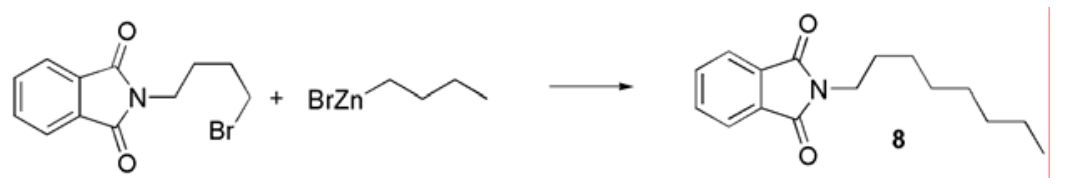


(Table 3, entry 3). Following the general procedure, $n$-butylzinc bromide $(1.3 \mathrm{~mL}$ of a $0.5 \mathrm{M}$ THF solution, $0.65 \mathrm{mmol}$ ) and $N$-(4-bromobutyl)phthalimide (141.0 $\mathrm{mg}, 0.5 \mathrm{mmol}$ ) provided 84 mg of $8,{ }^{3} 65 \%$ yield after column chromatography (hexane:ethyl acetate $=8: 1 ; R f=0.22$ ). The ${ }^{1} \mathrm{H}$ and ${ }^{13} \mathrm{C}$ NMR spectra were identical to the spectra previously reported.

\section{Ethyl 9-cyanononanoate (9) CAS \# [133309-93-0]}

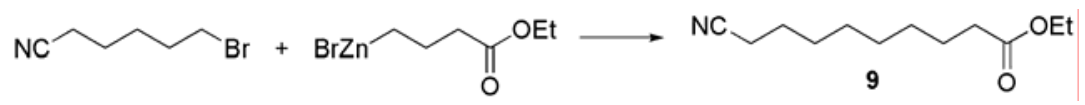

(Table 3, entry 5). Following the general procedure, 4-ethoxy-4-oxobutylzinc bromide (1.3 mL of a $0.5 \mathrm{M}$ THF solution, $0.65 \mathrm{mmol}$ ) and 6-bromohexanonitrile (88.0 $\mathrm{mg}, 66 \mu \mathrm{L}, 0.5 \mathrm{mmol})$ provided $66 \mathrm{mg}$ of $9,{ }^{4} 62 \%$ yield after column chromatography (pentane:ethyl acetate $=20: 1 ; R f$ $=0.1) .{ }^{1} \mathrm{H} \mathrm{NMR}\left(\mathrm{CDCl}_{3}, 400 \mathrm{MHz}\right) \delta 4.12(\mathrm{q}, J=7.2 \mathrm{~Hz}, 2 \mathrm{H}), 2.34(\mathrm{t}, J=7.1 \mathrm{~Hz}, 2 \mathrm{H}), 2.29(\mathrm{t}, J$ $=7.5 \mathrm{~Hz}, 2 \mathrm{H}), 1.65(\mathrm{~m}, 4 \mathrm{H}), 1.44(\mathrm{t}, J=6.1 \mathrm{~Hz}, 2 \mathrm{H}), 1.33(\mathrm{~m}, 6 \mathrm{H}), 1.25(\mathrm{t}, J=7.2 \mathrm{~Hz}, 3 \mathrm{H}) .{ }^{13} \mathrm{C}$ $\left.\mathrm{NMR} \mathrm{CDCl}_{3}, 100 \mathrm{MHz}\right) \delta 177.8,119.8,60.2,34.2,28.9(2 \mathrm{C}), 28.6(2 \mathrm{C}), 25.3,24.9,17.1,14.3$.

\section{Ethyl 7-phenylheptanoate (10) [134511-26-5]}

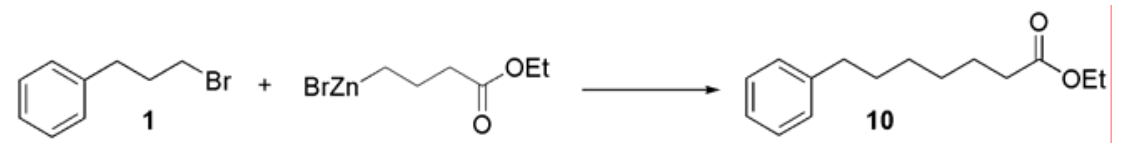

(Table 3, entry 6). Following the general procedure, 4-ethoxy-4-oxobutylzinc bromide (1.3 mL of a $0.5 \mathrm{M}$ THF solution, $0.65 \mathrm{mmol})$ and 3-bromopropylbenzene (99.5 $\mathrm{mg}, 76 \mu \mathrm{L}, 0.5 \mathrm{mmol})$ provided $89 \mathrm{mg}$ of 10, ${ }^{5} 76 \%$ yield after column chromatography (pentane:ethyl acetate $=20: 1$; $R f=0.25)$. The ${ }^{1} \mathrm{H}$ and ${ }^{13} \mathrm{C}$ NMR spectra were identical to the spectra previously reported.

\section{2-Undecanyl-1,3-dioxolane (11) CAS \# [5735-88-6]}




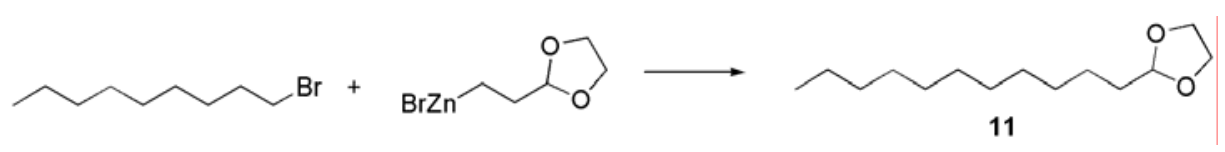

(Table 3, entry 7). Following the general procedure, [2-(1,3-dioxolan-2-yl)]-ethylzinc bromide (1.3 mL of a $0.5 \mathrm{M}$ THF solution; $0.65 \mathrm{mmol})$ and $n$-nonylbromide (103.6 mg, $95 \mu \mathrm{L}, 0.5 \mathrm{mmol})$ provided $75 \mathrm{mg}$ of $11,{ }^{6} 66 \%$ yield after column chromatography (pentane:diethyl ether $=95: 5$; $R f=0.25)$. The ${ }^{1} \mathrm{H}$ and ${ }^{13} \mathrm{C}$ NMR spectra were identical to the spectra previously reported.

\section{2-(5-phenylpentyl)-1,3-dioxolane (12)}

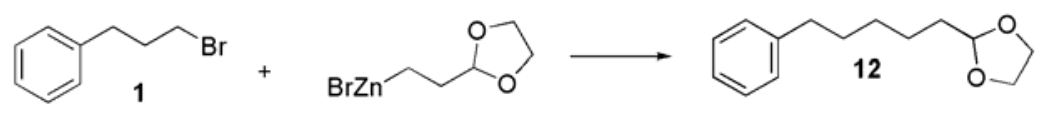

(Table 3, entry 8). Following the general procedure, [2-(1,3-dioxolan-2-yl)]-ethylzinc bromide (1.3 mL of a $0.5 \mathrm{M}$ THF solution; $0.65 \mathrm{mmol})$ and 3-bromopropylbenzene $(99.5 \mathrm{mg}, 76 \mu \mathrm{L}, 0.5$ mmol) provided $77 \mathrm{mg}$ of 12, $70 \%$ yield after column chromatography (pentane:diethyl ether $=$ 9:1; $R f=0.32) .{ }^{1} \mathrm{H} \mathrm{NMR}\left(\mathrm{CDCl}_{3}, 400 \mathrm{MHz}\right): \delta 7.32-7.19(\mathrm{~m}, 5 \mathrm{H}), 4.87(\mathrm{t}, J=3.6 \mathrm{~Hz}, 1 \mathrm{H}), 4.01-$ $3.98(\mathrm{~m}, 2 \mathrm{H}), 3.88-3.85(\mathrm{~m}, 2 \mathrm{H}), 2.64(\mathrm{t}, J=7.5 \mathrm{~Hz}, 2 \mathrm{H}), 1.68-1.63(\mathrm{~m}, 4 \mathrm{H}), 1.50-1.41(\mathrm{~m}, 4 \mathrm{H})$.

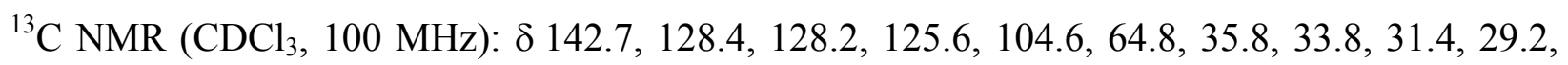
23.9. Anal. Calcd. For $\mathrm{C}_{14} \mathrm{H}_{20} \mathrm{O}_{2}$ : C, 76.33; H, 9.15. Found C, 76.46; H, 9.47.

\section{(6-(1, 3-dioxolan-2-yl) hex-1-ynyl)trimethylsilane) (13)}

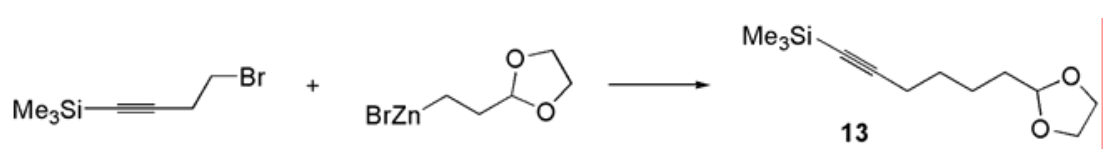

(Table 3, entry 9). Following the general procedure, [2-(1,3-dioxolan-2-yl)]-ethylzinc bromide (1.3 mL of a $0.5 \mathrm{M}$ THF solution; $0.65 \mathrm{mmol})$ and 4-trimethylsilyl-1-bromobut-3-yne (105 mg, $0.5 \mathrm{mmol}$ ) provided $69 \mathrm{mg}$ of 13, $61 \%$ yield after column chromatography (pentane:diethyl ether $=19: 1 ; R f=0.1) .{ }^{1} \mathrm{H}$ NMR $\left(\mathrm{CDCl}_{3}, 400 \mathrm{MHz}\right): \delta 4.87(\mathrm{t}, J=4.6 \mathrm{~Hz}, 1 \mathrm{H}), 4.00-3.97(\mathrm{~m}$, 
2H), 3.88-3.85 (m, 2H), $2.25(\mathrm{t}, J=6.7 \mathrm{~Hz}, 2 \mathrm{H}), 1.71-1.67(\mathrm{~m}, 2 \mathrm{H}), 1.61-1.51(\mathrm{~m}, 4 \mathrm{H}) 0.16(\mathrm{~s}$ 9H). ${ }^{13} \mathrm{C} \mathrm{NMR}\left(\mathrm{CDCl}_{3}, 100 \mathrm{MHz}\right) \delta 107.3,104.5,84.5,64.9,33.3,28.5,23.3,19.8,0.17$. Anal. Calcd. For $\mathrm{C}_{12} \mathrm{H}_{22} \mathrm{O}_{2} \mathrm{Si}$ : C, 63.66; H, 9.80. Found C, 63.51; H, 10.18 .

8-(1, 3-dioxolan-2-yl)-2,2-dimethyl octanenitrile (14)

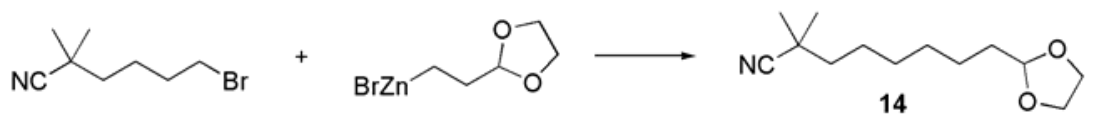

(Table 3, entry 10). Following the general procedure, [2-(1,3-dioxolan-2-yl)]-ethylzinc bromide (1.3 mL of a $0.5 \mathrm{M}$ THF solution; $0.65 \mathrm{mmol})$ and 6-bromo-2,2-dimethylhexanenitrile (102.0 $\mathrm{mg}$, $85 \mu \mathrm{L}, 0.5 \mathrm{mmol}$ ) provided $84.6 \mathrm{mg}$ of $\mathbf{1 4}, 75 \%$ yield after column chromatography (pentanediethyl ether $=4: 1 ; R f=0.18) .{ }^{1} \mathrm{H} \mathrm{NMR}\left(\mathrm{CDCl}_{3}, 400 \mathrm{MHz}\right): \delta 4.86(\mathrm{t}, J=4.8 \mathrm{~Hz}, 1 \mathrm{H}), 4.00-3.97$ $(\mathrm{m}, 2 \mathrm{H}), 3.91-3.85(\mathrm{~m}, 2 \mathrm{H}), 1.70-1.65(\mathrm{~m}, 2 \mathrm{H}), 1.45-1.29(\mathrm{~m}, 10 \mathrm{H}), 1.27(\mathrm{~s}, 6 \mathrm{H}) .{ }^{13} \mathrm{C}$ NMR $\left(\mathrm{CDCl}_{3}, 100 \mathrm{MHz}\right): \delta$ 125.3, 104.6, 64.9, 41.0, 33.8, 32.4, 29.5, 29.3, 26.7, 25.2, 24.0. Anal. Calcd. For $\mathrm{C}_{13} \mathrm{H}_{23} \mathrm{NO}_{2}$ : C, 69.29; H, 10.29; N, 6.22. Found C, 69.67; H, 10.40; N, 5.91. 


\section{Spectral Data}

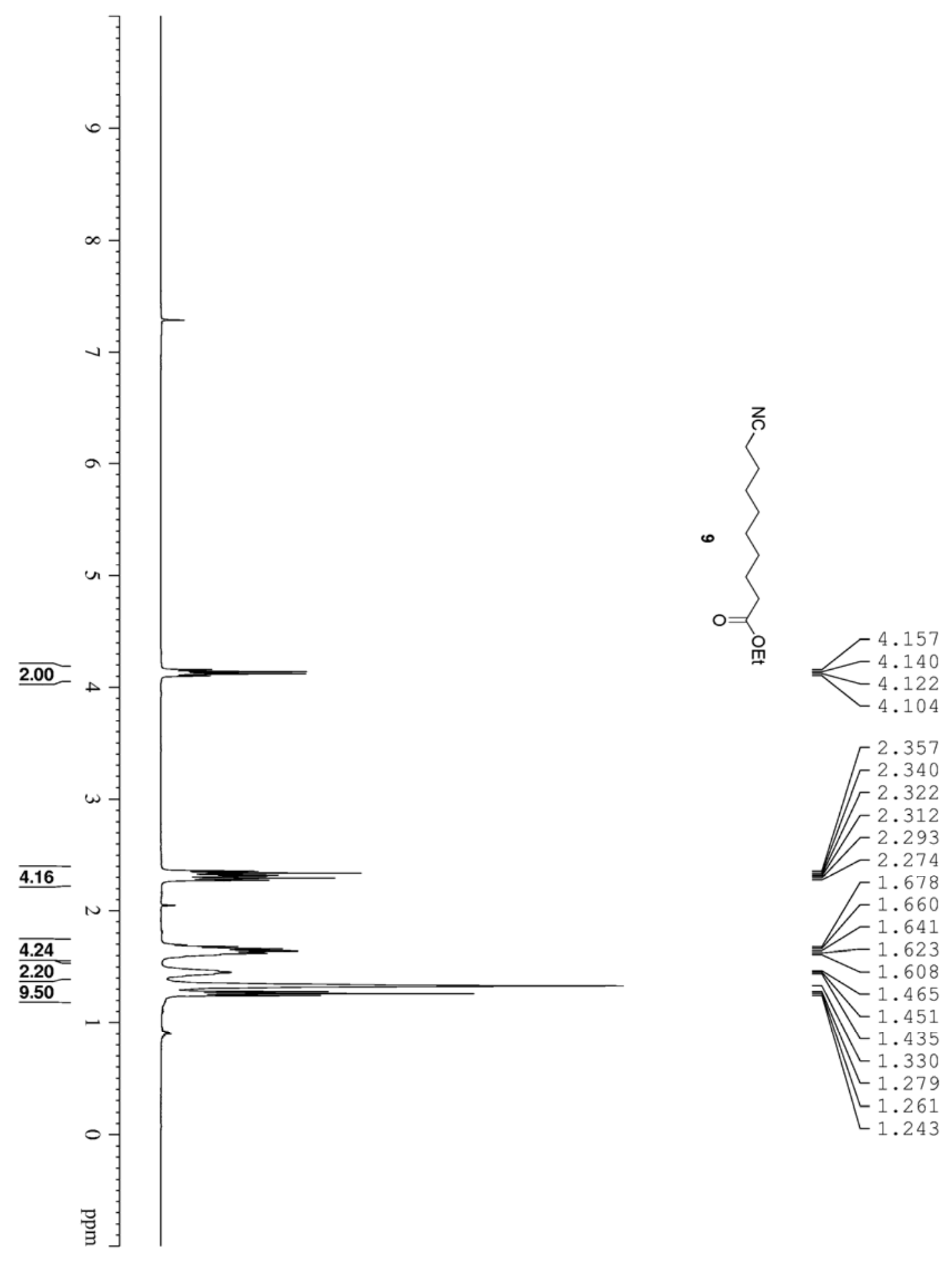




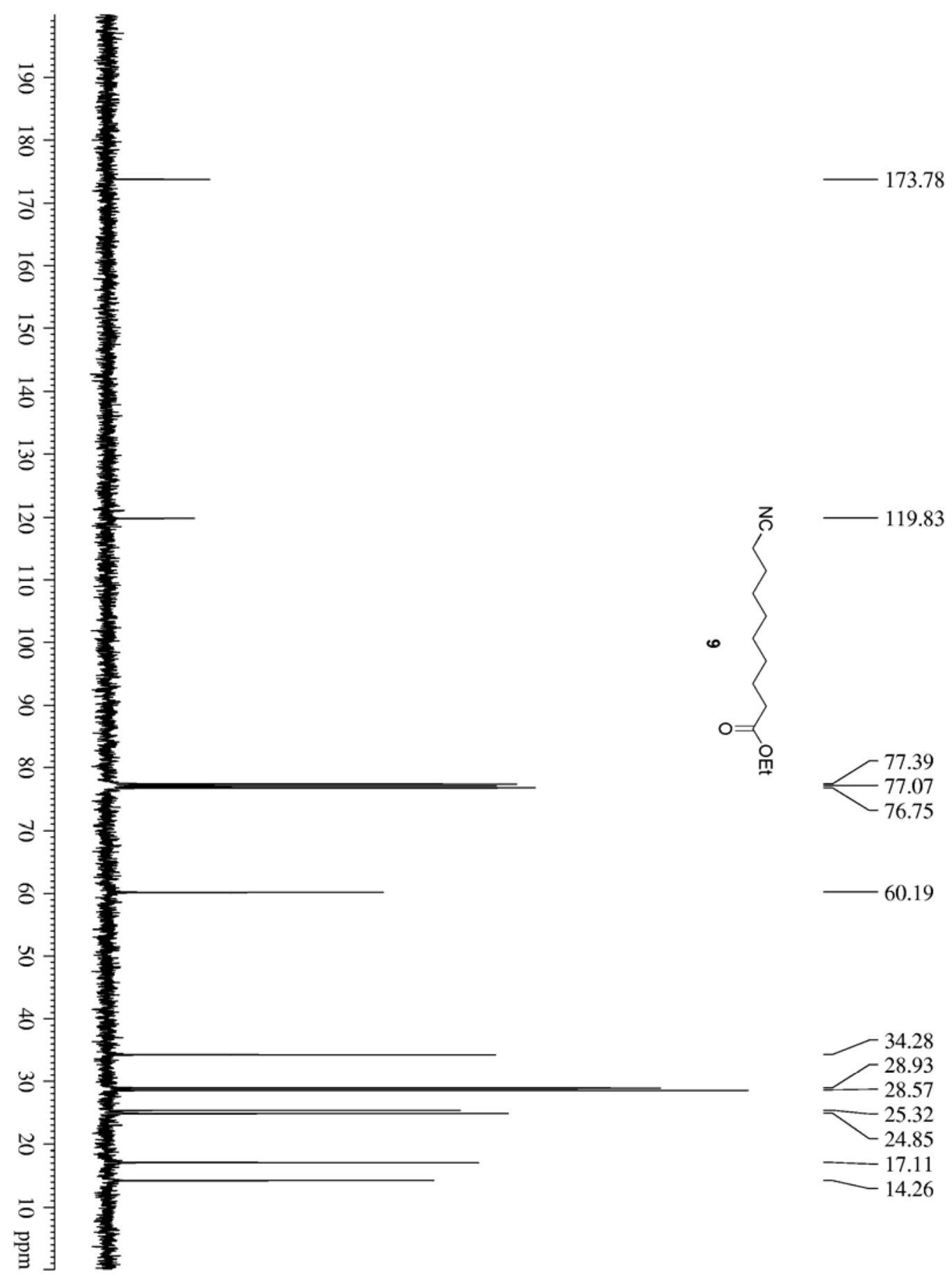




\section{References.}

1. Arduengo, III, A. J.; Krafczyk, R.; Schutzler, R Tetrahedron 1999, 55, 14523-14534.

2. Leonard, J.; Lygo, B.; Procter, G. Advanced Practical Organic Chemistry, 2nd ed; Blackie Acedemic \& Professional: Oxford, 1995; pp 96-97.

3. Martin, B.; Sekljic, H.; Chassaing, C. Org. Lett. 2003, 5, 1851-1853

4. Yoshida, H.; Kakeya, N.; Kashiwagi, M. Preparation of $\alpha$-( $\omega$-cyanoalkanoyl)- $\gamma-$ butyrolactones. Eur. Pat. Appl. 0402063, Dec 12, 1990.

5. Labaudiniere, R.; Hilboll, G.; Leon-Lomeli, A.; Lautenschläger, H-H.; Parnham, M.; Kuhl, P., Dereu, N. J. Med. Chem. 1992, 35, 3156-3169.

6. Arterburn, J. B.; Perry, M. C. Org. Lett. 1999, 1, 769-771. 